\title{
Mechanisms of resistance in sorghum to head bug, Calocoris angustatus
}

\author{
H.C. Sharma \& V.F. Lopez \\ International Crops Research Institute for the Semi-Arid Tropics (ICRISAT), Patancheru. Andhra \\ Pradesh 502 324. India
}

Accepted: July 31, 1990

Key words: Head bug, Calocoris angustatus, sorghum, resistance mechanisms, preference, antibiosis, consumption and utilization of food

\begin{abstract}
Cultivar preference/nonpreference for feeding is one of the components of resistance to the sorghum head bug, (alocoris angustatus Lethicry (Hemiptera: Miridae). IS 2761, IS 9692, IS 17610, IS 17618 and IS 17645 were not preferred by the adults of $C$. angustatus under multi- or two-choice conditions. However, cultivar preference was not evident under no-choice tests or headcage conditions.

Reduced oviposition is an important component of resistance to head bugs in IS 17645, IS 17610 and IS 17618. Post-embryonic development was extended by 1-2 days when nymphs were fed on these genotypes. Fifth instar nymphs and adults had lower weights when reared on IS 17610 and IS 9692. Nymphal survival was relatively lower on IS 9692, IS 17610 and IS 17645.

Fourth instar nymphs were relatively less efficient in food utilization when fed on grain of IS 2761 and IS 6984 as compared with the susceptible cultivars CSH 5 and Swarna. Stage of grain development influenced the indices of consumption and utilization of food by head bugs. Consumption index (CI) and growth rate was lower on 20-day-old grain of IS 2761 as compared with 12-day-old grain.
\end{abstract}

\section{Introduction}

Sorghum, Sorghum bicolor (L.) Moench is an important cereal crop in Asia, Africa, and Latin America. Mirid head bugs (Calocoris angustatus Leth., Creontiades pallidus Ramb., Eurystylus immaculatus Odh. and (ampylomma spp.) (Hemiptera : Miridae) are major pests of sorghum grain in Asia and Africa. C. angustatus is the predominant species in India (Sharma, 1985), and damage by this species was found to result in yield loss of 55-88\% (Sharma \& Lopez, 1989) at ICRISAT Center. In different parts of India, avoidable losses of $6.6-84 \%$ have been computed (Leuschner \& Sharma, 1983). Adults and nymphs suck sap from the devcloping grain, which remain unfilled, shrivel, and in severe infestations, become completely chaffy.

Among the various pest control methods, host plant resistance is an important component in head bug control (Sharma \& Lopez, 1990). The identification of sources of resistance and the knowledge of different mechanisms involved are essential for increasing the levels and diversity of resistance, and transferring such resistances into high-yielding cultivars. This paper reports the studies conducted at ICRISAT Center, India, on the mechanisms of resistance in sorghum to C. angustatus. 


\section{Materials and methods}

Cultivar preference. To study the differences in cultivar preference to adults under multi-choice field conditions, a set of 10 cultivars was planted in the field in 4-row plots $(4 \mathrm{~m}$ long, ridges $75 \mathrm{~cm}$ apart, and $10 \mathrm{~cm}$ spacing between plants) with three replications in a completely randomized block design. Normal agronomic practices were followed for raising the crop (Sharma \& Lopez, 1990). Head bug preference/nonpreference was measured as the number of head bugs attracted to the panicles of different genotypes at the preanthesis stage, when the adult head bugs select their host plant for oviposition and feeding. Five randomly selected panicles per plot were sampled in a polyethylene bag $(30 \times 45 \mathrm{~cm})$ at preanthesis. This procedure was repeated at the milk stage (15-days-after anthesis). The former measured cultivar preference and acceptance for oviposition and feeding, while the latter also measured the extent of oviposition, cultivar acceptance for feeding and antibiosis. Head bug population build up was also studied under no-choice conditions in the headcage to differentiate between preference and other mechanisms of resistance. Five randomly selected panicles per plot were caged with 10 pairs of head bugs per panicle at the pre-anthesis stage. Head bug numbers were counted 20-days-after infestation (Sharma \& Lopez, 1990).

Cultivar preference was also studied under laboratory conditions by using a transparent cylindrical enclosure $(50 \mathrm{~cm}$ diameter, $50 \mathrm{~cm}$ high). Sorghum panicles at the pre-anthesis or milk stage were placed vertically inside the container in $100 \mathrm{ml}$ conical flasks containing water. Adults which had been reared on CSH 1, a susceptible cultivar, were placed in the center of the container and allowed to select their host plant. Fifty pairs of adults were released in each test. Each experiment was repeated 10 times. The number of head bugs found on the panicles of each genotype were recorded after $12 \mathrm{~h}$. The position of cultivars was changed in each test to avoid position effects.

During the $1986 / 87$ postrainy season, cultivar preference was studied under multi- and twochoice conditions. Under multi-choice conditions, six cultivars were offered to the head bugs at the $50 \%$ anthesis or milk stage. The panicles were covered with a muslin cloth bag to avoid direct contact between the insect and the host plant. The panicles were held vertically in a $100 \mathrm{ml}$ flask containing water. Fifty pairs of head bugs were released in the center of the container and the number of bugs found on the covered panicles of each genotype was recorded after $4 \mathrm{~h}$. Under two-choice conditions, panicles of a less susceptible genotype (IS 2761, IS 17610, IS 17618 or IS 17645) and the susceptible check, CSH 1, were offered to the bugs in the container. Other experimental details were as described earlier.

We also studied the cultivar preference of fifth instar nymphs to the 15-day-old milk grain. The grain of a resistant (IS 2761 or IS 17618) and a susceptible cultivar ( $\mathrm{CSH} \mathrm{1)}$ were offered to the bugs in double- or no-choice tests. Under nochoice conditions, milk grain of only one genotype were placed in the center of the petri dish. The number of head bugs found on each genotype were recorded after $4 \mathrm{~h}$. The experiments were repeated 5-10 times, and cultivar position was changed in each experiment.

Oviposition. C. angustatus lays its eggs inside the spikelets at or before flowering. There is a wide variation in spikelet characteristics such as glume length, glume hairiness, grain hardness and glume coupling, and these traits may affect the suitability of a genotype for oviposition. Oviposition of C. angustatus was studied on eight genotypes in 1983 and on seven genotypes in 1984-85. Five pairs of head bugs were confined per panicle at the pre-anthesis stage in a headcage (Sharma \& Lopez, 1990). Five randomly selected panicles of each genotype were caged for 3 days under field conditions during the 1983 rainy season. Thereafter, panicles were brought to the laboratory and 250 randomly selected spikelets were dissected under a $10 \times$ microscope. The number of eggs and the number of florets with eggs were recorded. During the 1984-85 rainy and postrainy seasons, 
20) females were confined with the panicles for three days as described above, and 500 spikelets selected at random were observed for oviposition.

Antibiosis. Studies on the post-embryonic development of $C$. angustatus were conducted on five less susceptible and three highly susceptible cultivars under laboratory conditions $\left(27 \pm 1{ }^{\circ} \mathrm{C}\right.$ and $65 \pm 5 \%$ R.H.). Panicles of $\mathrm{CSH} 1$ were caged with 10 pairs of head bugs per panicle at the pre-anthesis stage for 3 days in the field. Five days after infestation, the panicles were taken to the laboratory. Newly emerged 1 st instar nymphs were collected from these panicles, and individually confined with 15-day-old milk grain of different genotypes in a glass vial $(2.5-\mathrm{cm}$ diameter, $10-\mathrm{cm}$ long). The vials were closed with a cotton plug. There were 20 insects under observation in each genotype. Food was changed every day. Data were recorded on the duration of postembryonic development and the mass of fifth instar nymphs and adults.

Survival of first instar nymphs was studied on seven genotypes under field conditions. One hundred, 250, and 500 nymphs per panicle were confined with the panicles of different genotypes at the complete-anthesis stage (6 days after anthesis) which coincides with the emergence of first instar nymphs under natural conditions. Five randomly selected panicles were infested at each level in each genotype. The number of head bugs surviving on each genotype were recorded after 15 days.

Consumption and utilization of food. Indices of food consumption and utilization $(\mathrm{CI}=\mathrm{con}$ sumption index, $\mathrm{ECI}=$ efficiency of conversion of ingested food into body matter, and $\mathrm{GR}=$ growth rate) were computed on a wet weight basis (Sharma \& Agarwal, 1982; Waldbauer, 1968). Consumption and utilization of food by the fifth-instar nymphs were studied on 15-day-old grain of two moderately resistant (IS 6984 and IS 2761) and two susceptible (CSH 5 and Swarna) cultivars, grown under field conditions as described above. Panicles tagged at $50 \%$ anthesis were excised 15-days-after flowering and brought to the laboratory. Fifty grains were picked out randomly from the mid-portion of the panicle, and weighed immediately on a Mettlar (R) balance. Ten pre-weighed 4th-instar nymphs, starved for $4 \mathrm{~h}$, were confined with the food for $48 \mathrm{~h}$. Bugs were confined with the grain in a petri dish (7.5-cm diameter). To maintain grain turgidity and minimize natural loss of water, a filter paper moistened with $1 \mathrm{ml}$ distilled water, was provided in the petri dish. An aliquot of 50 grain was similarly kept in a petri dish, but without bugs, to serve as a control to compute natural loss in grain weight. The tests were repeated 10 times for each genotype per treatment. Food utilization indices were also computed for IS 6984, IS 2761 and $\mathrm{CSH} 5$ on 12-, and 20-day-old grain. Other experimental details were the same as described before.

Statistical analysis. Data were subjected to analysis of variance to compute standard error of mean. Least significant difference (LSD) was used to compare treatment means. Data on oviposition was converted to square root values and then subjected to analysis of variance to minimize the coefficient of variance. Various indices on consumption and utilization of food were computed as described by Waldbauer (1968) and as adapted for fresh weight basis by Sharma \& Agarwal (1982).

\section{Results}

Cultivar preference. There were significant differences between genotypes in head bug numbers recorded at panicle emergence (Table 1). Four genotypes (IS 1335, IS 17610, IS 17618 and IS 17645) were relatively less preferred than the susceptible checks CSH 1 and/or CSH 5. Five lines (IS 61, IS 2761, IS 17610, IS 17618 and IS 17645 ) had lower head bug population ( $<52$ bugs per panicle) than the susceptible checks (106-115 bugs per panicle) at the milk stage under natural conditions. However, only three lines, IS 17610, IS 17618 and IS 17645, had lower head bug population build up under no-choice conditions in the 
7able 1. Cultivar preference and population buld up of sorghum head bug, Calocoris angustatus, under natural and headcage conditions, ICRISAT Center, rany season 1982 and postrany season 1982/83

\begin{tabular}{|c|c|c|c|}
\hline \multirow[t]{2}{*}{ Genotype } & \multicolumn{2}{|c|}{$\begin{array}{l}\text { No. of head bugs per } \\
\text { pancle under natural } \\
\text { conditions }\end{array}$} & \multirow{2}{*}{$\begin{array}{l}\text { Population buıld up } \\
\text { under headcage } \\
\text { (10 pairs of adults } \\
\text { per panıcle) }\end{array}$} \\
\hline & $\begin{array}{l}\text { Panicle } \\
\text { emergence }\end{array}$ & Milk & \\
\hline IS 6 I & $11(3.1)^{\mathrm{b} x 1}$ & $52(6.2)^{\mathrm{atb}}$ & $285(16.4)^{\mathrm{cd}}$ \\
\hline IS 1335 & $7(2.7)^{\mathrm{ah}}$ & $274(15.9)^{\mathrm{d}}$ & $172(13.0)^{\mathrm{bed}}$ \\
\hline IS 2761 & $12(2.9)^{\mathrm{abc}}$ & $43(57)^{\mathrm{ab}}$ & $159(10.2)^{\mathrm{ah}}$ \\
\hline IS 4686 & $25(4.7)^{d}$ & $198(12.8)^{\mathrm{cd}}$ & $309(16.7)^{\mathrm{cd}}$ \\
\hline IS 7790 & $18(4.1)^{\mathrm{cd}}$ & $157(11.5)^{c}$ & $161(12.4)^{\mathrm{bc}}$ \\
\hline IS 17610 & $3(1.5)^{\prime \prime}$ & $18(3.4)^{\mathrm{a}}$ & $89(9.3)^{\mathrm{ab}}$ \\
\hline IS 17618 & $8(2.5)^{\mathrm{ab}}$ & $19(3.6)^{a}$ & $89(9.4)^{\mathrm{ath}}$ \\
\hline IS 17645 & $6(2.1)^{\mathrm{ab}}$ & $13(3.0)^{a}$ & $37(6.0)^{4}$ \\
\hline $\mathrm{CSH} I$ & $13(3.5)^{\mathrm{bcd}}$ & $106(8.6)^{\mathrm{bc}}$ & $280(16.7)^{\mathrm{cd}}$ \\
\hline CSH 5 & $18(40)^{c d}$ & $115(9.1)^{b c}$ & $345(18.2)^{\mathrm{d}}$ \\
\hline Mean & $12(3.1)$ & $100(8.0)$ & $192(12.8)$ \\
\hline$S E( \pm)$ & $(0.52)$ & $(145)$ & $(1.91)$ \\
\hline $\operatorname{CV}\left({ }_{0}^{\circ}\right)$ & $(16.7)$ & $(18.1)$ & $(211)$ \\
\hline
\end{tabular}

1 Figures in parentheses are square root transformations Figures followed by the same letter in a column are not significantly different at $\mathrm{P}<0.05$.

headcage. The lower head bug numbers in IS 61 , IS 1335, and IS 2761 under natural conditions may be due to preference/nonpreference by the adults, which was eliminated under no-choice conditions in the headcage.

Under laboratory conditions, IS 6984 and IS 2761 were relatively less preferred than the susceptible check, CSH 5 during the 1983 rainy season (Fig. 1). However, fewer adults were recorded on Swarna as well at the pre-anthesis stage. Sixty-one and $88 \%$ of the bugs released responded at the half-anthesis and milk stages, respectively. During the $1986 / 87$ postrainy season, IS 17610, IS 17618, and IS 17645 were less preferred by the head bugs at anthesis and milk stages (Fig. 2). Relatively more bugs were recorded on IS 2761 and IS 9692 . However, these genotypes were also significantly less preferred than the susceptible check, $\mathrm{CSH} 5$. Fifty to $62^{\circ}$ '" of the bugs released responded to panicle odors.

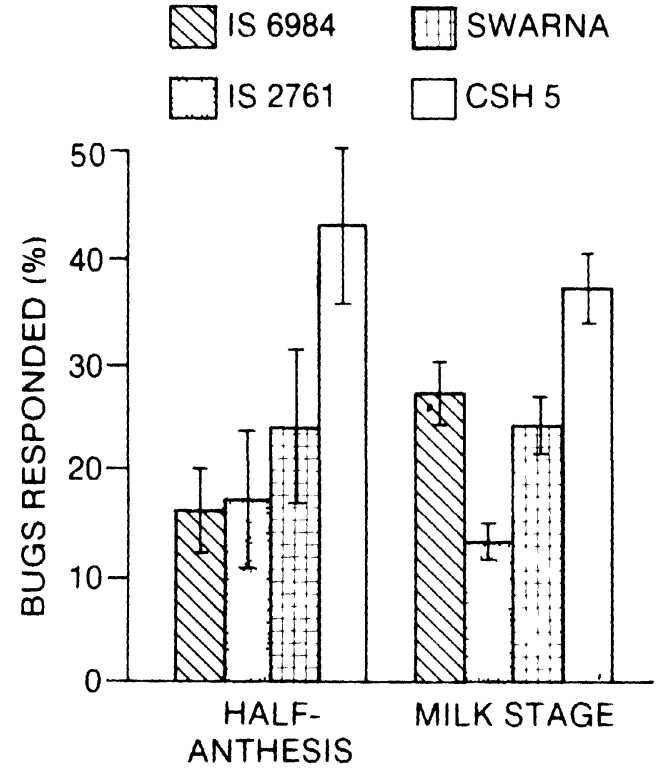

Fig 1 Relative preference of C angustatus adults to four sorghum genotypes under multi-choice conditions (rainy season,

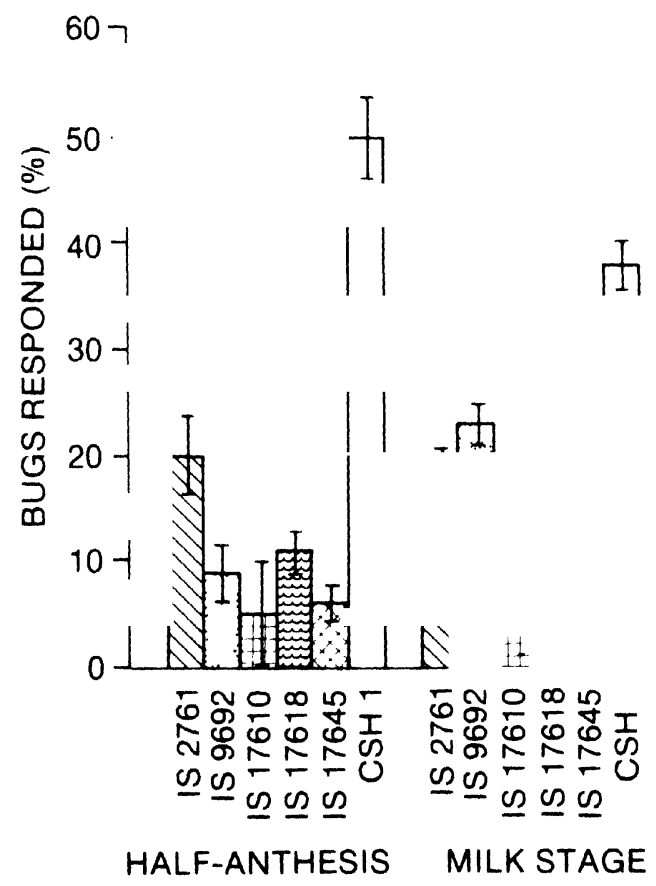

Fig. 2. Relative preference of $C$. angustatus adults to six sorghum genotypes under multi-choice conditions (postraıny season, 1986/87). 
Under two-choice tests, IS 2761, IS 9692, IS 17610, IS 17618 and IS 17645 were significantly less preferred than the susceptible check, CSH 1 , at the half-anthesis and milk stages (Fig. 3). Nearly $70^{\circ}{ }_{0}$ of bugs released responded to the sorghum panicles. This further confirmed the differences in cultivar nonpreference observed under multi-choice conditions.

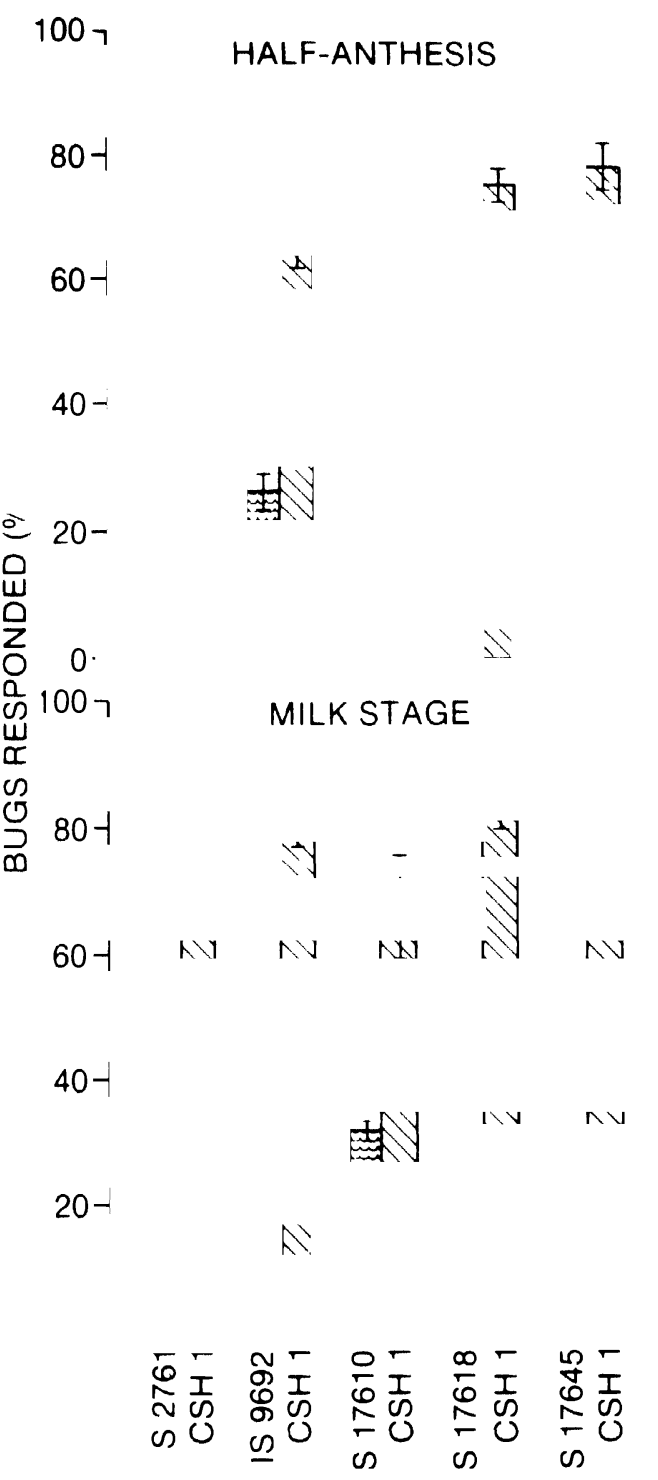

Fig. 3. Relative preference of C. angustatus adults to five sorghum genotypes in relation to the susceptible check, ( $\mathrm{SH}$ 1, under two-choice conditıons (postramy season, 1986/87).

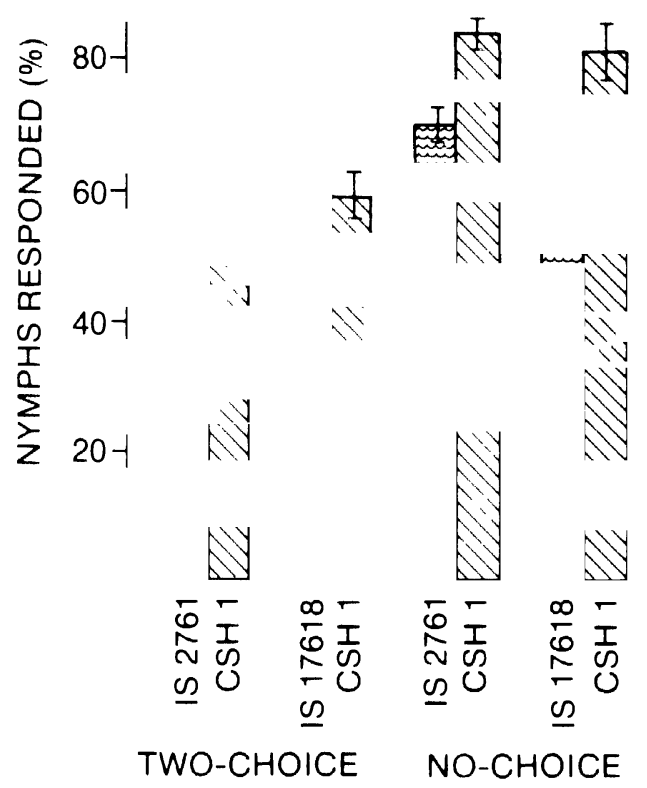

Fig. 4. Relative preference of the fifth-instar nymphs of C. angustatus under two-and no-choice conditions to the milk gran of three genotypes (postrany season, 1986,87).

Under two-choice tests, both IS 2761 and IS 17618 were significantly less preferred by the nymphs than the susceptible check $\mathrm{CSH} 1$ (Fig. 1). Head bug response was $74-93^{\circ}{ }^{\circ}$ in different tests. Under no-choice conditions, the differences in bug response to the panicles of relatively resistant and the susceptible cultivars were less pronounced, indicating that the cultivar nonpreference tends to break down under no-choice conditions. Nymphal response to sorghum grain was $69-84^{\circ}$.

Oviposition. The number of eggs laid was lowest in IS 17610 (9 eggs per 250) spikelets) during the 1983 rainy season (Table 2). IS 17610 and IS 17645 had relatively fewer florets with eggs $(<9$ spikelets with eggs per 100 spikelets compared to 18-19 in CSH 5, CSH 9, and Swarna). In further tests during 1984-85, IS 17645 was less preferred for oviposition than the susceptible checks (Table 3). Extent of oviposition seems to be an important factor in cultivar susceptibility to head 
Table 2. Oviposition behavior of Calocoris angustatus on six cultivars, ICRISAT Centcr, rainy season 1983

\begin{tabular}{|c|c|c|}
\hline Cultivar & $\begin{array}{l}\text { No. of eggs/ } \\
250 \text { florets }\end{array}$ & $\begin{array}{l}\text { No. of florets with } \\
\text { eggs/100) florets }\end{array}$ \\
\hline IS 2761 & $225(15.0)^{\mathrm{d}}$ & $41^{\mathrm{d}}$ \\
\hline IS 9692 & $93(9.6)^{\mathrm{bc}}$ & $11^{\text {the }}$ \\
\hline IS 17610 & $9(2.6)^{u}$ & $3^{4}$ \\
\hline IS 17618 & $78(8.7)^{\mathrm{b}}$ & $14^{b x}$ \\
\hline IS 17645 & $50(7.1)^{\mathrm{b}}$ & $9^{.4 h}$ \\
\hline $\mathrm{CSH} 5$ & $129(11.3)^{k}$ & $18^{\mathrm{hc}}$ \\
\hline $\mathrm{CSH} 9$ & $81(8.9)^{\mathrm{bc}}$ & $19^{\circ}$ \\
\hline Swarna & $80(8.9)^{b x}$ & $18^{b x}$ \\
\hline $\operatorname{SE}( \pm)$ & $(0.88)$ & 3.1 \\
\hline CV $\left({ }_{0}^{0}\right)$ & $(14.3)$ & 12.9 \\
\hline
\end{tabular}

Figures in parentheses are square root transformations. Figures followed by the same letter in a column are not significantly different at $\mathrm{P}<0.05$.

bugs. IS 2761 and IS 9692 were non-preferred for feeding but the bugs oviposited successfully in the spikelets of these genotypes.

Antibiosis. Post-embryonic development was prolonged by 1-2 days on IS 17645 and IS 17610 compared to $\mathrm{CSH} 1, \mathrm{CSH} 5$ and $\mathrm{CSH} 9$ (Table 4). The mass of fifth-instar nymphs and
Table 4. Post-embryonic development of C. angustatus Leth. on eight sorghum cultıvars, ICRISAT Center, postrainy season 1985/86

\begin{tabular}{|c|c|c|c|c|}
\hline \multirow[t]{2}{*}{ Cultivar } & \multirow{2}{*}{$\begin{array}{l}\text { Developmental } \\
\text { period (days) }\end{array}$} & \multicolumn{2}{|l|}{ Mass (g) } & \multirow{2}{*}{$\frac{\text { Sex ratio }}{\phi: \delta}$} \\
\hline & & 5th instar & Adult & \\
\hline $\mathrm{CSH} 1$ & $9.3^{4}$ & $2.6^{\mathrm{ck}}$ & $3.8^{\circ}$ & $1: 2.0$ \\
\hline $\mathrm{CSH} 5$ & $9.3^{\prime \prime}$ & $2.4^{\mathrm{cd}}$ & $3.5^{\mathrm{dc}}$ & $1: 14$ \\
\hline $\mathrm{CSH} 9$ & $9.3^{4}$ & $2.8^{\circ}$ & $3.4^{\text {c de }}$ & $1: 1.3$ \\
\hline IS 2761 & $9.4^{\cdot 1}$ & $1.9^{\text {ath }}$ & $3.0^{\mathrm{hed}}$ & $1: 0.5$ \\
\hline IS 17618 & $9.4^{4}$ & $2.1^{b x}$ & $3.0^{\text {bucl }}$ & $1: 0.0$ \\
\hline IS 9692 & $9.7^{\prime \prime}$ & $2.0^{\text {sth }}$ & $2.5^{\mathrm{abb}}$ & $1: 0.0$ \\
\hline IS 17645 & $10.3^{\mathrm{b}}$ & $2.0^{\mathrm{ath}}$ & $2.8^{.16 x}$ & $1: 0.2$ \\
\hline IS 17610 & $11.0^{2}$ & $1.7^{\prime \prime}$ & $2.2^{\cdot 1}$ & $1 \cdot 0.0$ \\
\hline Mean & 9.70 & 2.21 & 3.0 & \\
\hline $\operatorname{SE}( \pm)$ & 0.176 & 0.127 & 0.223 & \\
\hline$C V\left({ }_{0}^{0}\right)$ & 7.90 & 25.10 & 32.30 & \\
\hline
\end{tabular}

Figures followed by the same letter in a column are not significantly different at $\mathrm{P}<0.05$.

adults was slightly less when the nymphs were reared on IS 9692, IS 17610 and IS 17645. However, in IS 2761 and IS 17618, fifth-instar and adult mass was at par with IS 17645 . Very low levels of antibiosis can be attributed to IS 9692 , IS 17645 and IS 17610. Prolonged development

Table 3. Oviposition behavior of Calocoris angustatus on seven cultivars, ICRISAT Center, 1984-85

\begin{tabular}{|c|c|c|c|c|}
\hline & \multicolumn{2}{|c|}{ No. of eggs $/ 500$ florets } & \multicolumn{2}{|c|}{ No. of florets with eggs $/ 100$ florets } \\
\hline & $\begin{array}{l}1984 \\
\text { rainy season }\end{array}$ & $\begin{array}{l}1984 / 85 \\
\text { postrainy season }\end{array}$ & $\begin{array}{l}1984 \\
\text { rainy season }\end{array}$ & $\begin{array}{l}1984 / 85 \\
\text { postrainy scason }\end{array}$ \\
\hline IS 2761 & $192(13.8)^{41}$ & $235(15.2)^{\mathrm{bc}}$ & $34^{\mathrm{ub}}$ & $47^{c}$ \\
\hline IS 6984 & - & $184(13.5)^{\mathrm{b}}$ & - & $35^{\mathrm{b}}$ \\
\hline IS 9692 & $450(21.1)^{\mathrm{h}}$ & $356(18.9)^{\mathrm{d}}$ & $03^{4}$ & 47 \\
\hline IS 17645 & $151(12.2)^{\mathrm{a}}$ & $88(8.9)^{4}$ & $21^{a}$ & $14^{4}$ \\
\hline $\mathrm{CSH} 1$ & $454(20.9)^{\mathrm{b}}$ & - & $60^{\mathrm{bc}}$ & - \\
\hline $\mathrm{CSH} 5$ & $254(15.9)^{\mathrm{a}}$ & $344(18.5)^{41}$ & $34^{\mathrm{ab}}$ & $30^{\mathrm{b}}$ \\
\hline Swrna & $562(23.7)^{\mathrm{h}}$ & $408(20.2)^{d}$ & $80^{c}$ & $51^{\prime}$ \\
\hline $\operatorname{SE}( \pm)$ & $(1.51)$ & $(1.20)$ & 9.1 & 3.8 \\
\hline $\mathrm{CV}\left({ }^{0}{ }_{0}\right)$ & $(29.2)$ & $(19.5)$ & 32.4 & 17.6 \\
\hline
\end{tabular}

' Figures in parentheses are square root transformations. Figures followed by the same letter in a column are not significantly different at $\mathrm{P}<0.05$. 
Table 5. Survival $(\%)$ of Calocoris angustatus 15-days-after release of first-instar nymphs on 8 sorghum genotypes, ICRISAT Center, rainy season 1985 and postrainy season 1985-86

\begin{tabular}{lcccc}
\hline Cultivar & 100 nymphs & 250 nymphs & 500 nymphs & Mean \\
\hline IS 2761 & 79 & 77 & 73 & $76^{\mathrm{b}}$ \\
IS 9692 & 86 & 54 & 43 & $62^{\mathrm{4}}$ \\
IS 17610 & 73 & 58 & 33 & $55^{\mathrm{b}}$ \\
IS 17618 & 90 & 97 & 72 & $86^{\mathrm{bc}}$ \\
IS 17645 & 84 & 47 & 38 & $56^{\circ}$ \\
CSH 1 & 81 & 75 & 73 & $76^{\mathrm{b}}$ \\
CSH 5 & 98 & 88 & 95 & $94^{\mathrm{b}}$ \\
CSH 9 & 98 & 85 & 59 & $81^{\mathrm{bc}}$ \\
Mean & 88 & 72 & 60 & \\
\hline
\end{tabular}

SF for comparing

$\begin{array}{ll}\text { Genotypes } & \pm 4.4 \\ \text { Infestation levels } & \pm 4.9 \\ \text { Genotypes } \times \text { infestation levels } & \pm 6.9\end{array}$

Figures followed by the same letter in a column are not significantly different at $P<0.05$.

and lower insect mass may be due to poor nutritional quality of the grain and/or antifeedant/ antibiotic effects of secondary plant substances present in these genotypes. Sex ratio was $<1$ on IS 2761 and relatively higher (>2) on $\mathrm{CSH} 5$. Further studies are needed to understand the genotypic effects on sex ratio in C. angustatus.

Survival of nymphs was lower on IS 17645 , IS 17610, and IS 9692 across infestation levels (Table 5). At 250 and 500 nymphs per panicle, IS 17610, IS 17645 and IS 9692 had significantly lower bug survival than the susceptible checks. At 100 nymphs/panicle, the differences in bug survival were less pronounced. Head bug survival decreased with increasing infestation level, which partly may be attributed to crowding. The differences between resistant and susceptible genotypes were more apparent at higher levels of infestation.

Consumption and utilization of food. Consumption index (CI) was lower on IS 6984 compared with IS 2761, CSH 5 and Swarna (Fig. 5). ECI and GR were very low on IS 6984 , followed by IS 2761. Swarna was most suitable for the growth $20\urcorner$
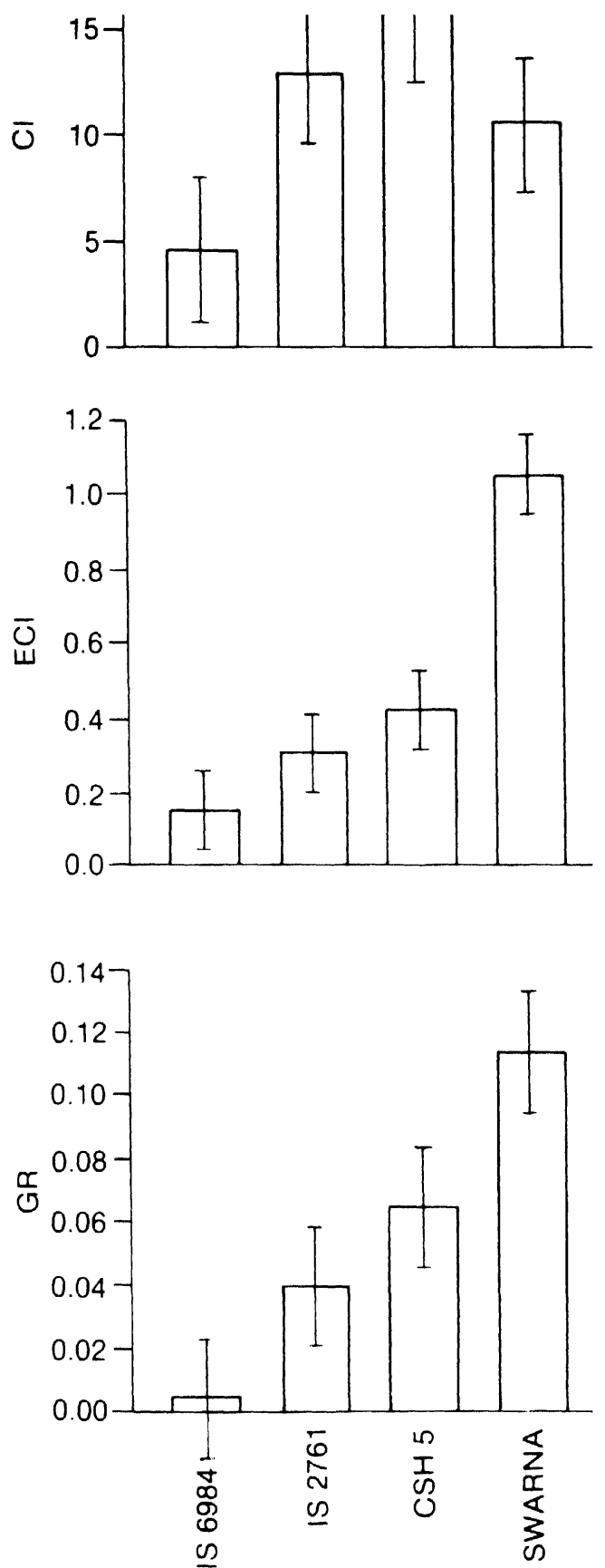

Fig. 5. Indices of consumption and utilization of food by the fifth-instar nymphs on four genotypes $(\mathrm{Cl}=$ Consumption index, $\mathrm{ECI}=$ Efficiency of conversion of inquested food into body matter and GR = Growth rate) (postrainy season, 1984/85). 

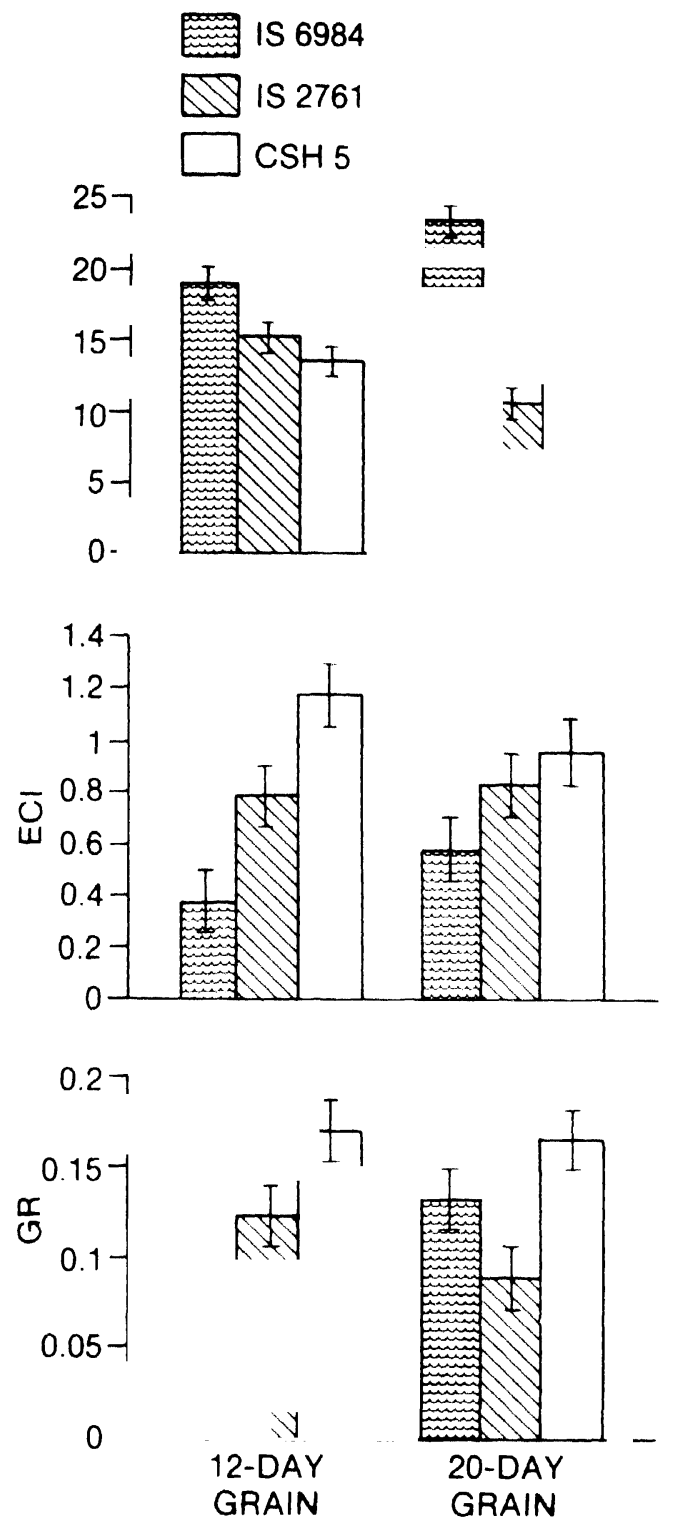

Fig. 6. Indices of consumption and utilization of food by the fifth-instar nymphs of $C$. angustatus in threc cultivars at two stages of grain development (postrainy season, 1983/84)(CI, ECI and GR - sec Fig. 5).

and development of fifth-instar nymphs. CSH 5 was relatively better than IS 6984 and IS 2761, but quite inferior as compared with Swarna.

ECI and GR were lower on IS 6984 and IS 2761 as compared with the susceptible check, CSH 5 (Fig. 6). However, differences in ECI and
GR were not significant between IS 2761 and CSH 5, and IS 6984 and CSH 5 on 20-day-old grain, respectively. $\mathrm{CI}$ and GR were lower on 20-day-old grain of IS 2761 and slightly higher on IS 6984 compared with 12-day-old. This may be due to differential biochemical changes in the grain during development in these genotypes.

\section{Discussion}

Cultivar nonpreference is the result of chemical and/or morphological characteristics of the host plant. It is an important component in host plant selection by head bugs for feeding and oviposition. Cultivar differences in host plant preference by head bugs were observed under field and laboratory conditions. IS 2761 , IS 6984 . IS 9692, IS 17610. IS 17618, and IS 17645 displayed some degree of nonpreference both at flowering and milky stage. This may be attributed to differential attraction, and/or differential host acceptance after landing and long term suitability of the host plant. However, nonpreference does not seem to be strong enough, and is eliminated under nochoice conditions, e.g., almost the same number of bugs were attracted to the panicles of IS 2761 , IS 17618 and CSH 1 under no-choice confinement tests. Similar observations have been reported for sorghum shoot fly (Atherigona soccata Rond.) (Jain \& Bhatnagar, 1962) and sorghum midge (Contarinia sorghicola Coq.) (Harris, 1961; Sharma et al., 1988). However, nonpreference can be used as a component of resistance to head bugs in combination with other mechanisms of resistance.

Reduced oviposition is also an important component of resistance. Differences in oviposition were evident under no-choice conditions in the headcage.

Antibiosis to head bugs in prolonging the developmental period or reducing insect mass was evident when the nymphs were reared on IS 9692, IS 17645 and IS 17610. These effects were not large enough to be a major component in cultivar resistance. Antibiotic effects of resistant cultivars on head bugs were also evident on the con- 
sumption and utilization of food by the head bugs. This may be due to the poor nutritional quality or antifeedant/antibiotic effects of secondary plant substances. Cultivars with a high concentration of secondary plant substances are not suitable for direct human consumption although such genotypes can be useful in brewing industry or in alternate uses of sorghum grain after pearling or chemical treatment (Novellie, 1981).

Cultivar preference, reduced oviposition, and antibiosis were identified in our studies as components of resistance to head bugs in sorghum. Different genotypes have different combinations of factors contributing to head bug resistance. Since levels of resistance to head bugs in the identified sources are low, efforts should be made to combine resistance from diverse sources to increase the levels and diversity of resistance to head bugs.

\section{Acknowledgements}

We thank Mr. V.V. Rao and Mr. S. Raja Rao for their assistance in these studies, and Dr. K.F. Nwanze and Dr. J.M.J. de Wet for their comments on the manuscript.

Approved as Journal Article No. 960) by the International Crops Research Institute for the Semi-Arid Tropics (ICRISAT), Patancheru, A.P., 502 324, India.

\section{Résumé}

Déterminisme de la résistance du sorgho à Calocoris angustatus

Les mécanismes de la résistance du sorgho à la punaise $C$. angustatus ont été examinés au champ et au laboratoire.

Les préférences des adultes ont été examinées avec choix multiples au champ et au laboratoire sur les 5 cultivars relativement moins sensibles (IS 2761, IS 9692, IS 17610, IS 17618, IS 17645) comparés aux hybrides commerciaux très sensibles (CSH 1, CSH 5, CSH 9). Les différences ont été confirmées avec des choix binaires au laboratoire. L'absence de préférence pour un cultivar est une des composantes de la résistance du sorgho à la punaise. Mais l'absence de préférence n'est cependant pas prouvée en cage au champ au par des expériences en olfactomètre sans choix au laboratoire.

La ponte a été étudié sur 8 'génotypes' pendant la saison des pluies de 1983 et sur 6 génotypes pendant la saison des pluies et après celle-ci en 1983-84. Les résultats montrent que la réduction de la ponte est une composante importante de la résistance sur IS 17645, IS 17610 et IS 17618.

Pour définir le niveau d'antibiose, l'étude du cycle a été menée au laboratoire sur 5 cultivars relativement peu sensibles (IS 2761, IS 9692, IS 17610, IS 176618, IS 17645) et 3 sensibles (CSH 1, CSH 5, CSH 9). Le développement postembryonnaire est prolongé d'un jour au deux quand les larves sont élevées sur grains laiteux de IS 17610 ou IS 17645. Les larves de $5^{\text {e }}$ stade et les adultes ont des poids plus faibles sur IS 17610 et IS 9692.

Les indices de consommation et d'utilisation des aliments ont été calculés pour IS 2761 , IS 6984, CSH 5 et Swarna; l'utilisation de grains de IS 2761 et IS 69884, comparée aux grains des cultivars CSH 5 et Swarna, est relativement moins efficace. $\mathrm{Cl}$ et $\mathrm{GR}$ sont plus faibles sur grains d'IS 2761 de 20 jours que de 12 jours.

\section{References}

Harris, K. M., 1961. The sorghum midge, Contarinia sorghicola (Coq.) in Nigeria. Bull. Ent. Res. 52: 129-146.

Jain, K. K. \& M. P. Bhatnagar, 1962. Studies on varietal resistance to jowar shoot fly. Indian J. Gen. 22: 224-229.

Leuschner, K. \& H. C. Sharma, 1983. Assessment of losses caused by sorghum panicle pests. Pages 201-213 in All India seminar on crop losses due to insect pests. 7-9 Jan 1983, Andhra Pradesh Agricultural University, Rajendranagar, Hyderabad, India.

Novellie, L., 1981. Fermented beverages. Pages 113-128 in Proceedings, International Symposium on Sorghum Grain Quality, 28-31 October 1981, ICRISAT Center, Patancheru. India.

Sharma, H. C., 1985. Screening for host plant resistance to mirid head bugs in sorghum. Pages 317-336 in Proceedings. International Sorghum Entomology Workshop. 15-21 July 
1984, Texas A \& M University, College Station, Tx, USA. Patancheru, A.P. 502 324, India. International Crops Rescarch Institute for the Semi-Arid Tropics.

Sharma, H. C. \& R. A. Agarwal, 1982. Consumption and utilization of bolls of different cotton genotypes by larvae of Earias vittella $\mathrm{F}$. and effect of gossypol and tannins upon food utilization. Zeit. Angew. Zool. 68: 13-37.

Sharma, H. C.\& V. F. L.opez, 1989. Assessment of avoidable losses and economic injury levels for the sorghum head bug, Calocoris angustatus Leth. (Hemiptera:Miridae). Crop Prot. 8: 429-435.
Sharma, H. C. \& V. F. Lopez, 1990. Screening for host plant resistance to sorghum head bug, Calocoris angustatus Leth. J. Insect Sci. Appl. (in press).

Sharma, H. C., P. Vidyasagar \& K. Leuschner, 1988. Nochoice cage technique to screen for resistance to sorghum midge (Diptera : Cecidomyiidae). J. Econ. Entomol. 81: 415-422.

Waldbauer, G. P., 1968. Consumption and utilization of food by insects. Adv. Insect Physiol. 5: 229-288. 